the higher numbers probably depending on fragmentation of some chromosomes. In many divisions in metaphase the number of chromosomes could not be exactly counted, but was estimated to fall between 32 and 40 . It is thus obvious that the division of the micromeres implies a reduction of the chromosome number to half.

Material of Strongylocentrotus drcebachiensis (O. F. Müller) was obtained on the west coast of Sweden. Also in this species the division of the micromeres yields haploid nuclei. The haploid number calculated from seventeen haploid and sixteen diploid chromosome counts was $20 \cdot 2$. This agrees well with that observed from an equatorial plate in polar view of a micromere. Here a pairing of the forty chromosomes is taking place, being equivalent to the 'secondary pairing' in mitosis (Diptera and polyploid plants) and meiosis (plants) (cf. Darlington ${ }^{4}$ ).

Somatic reduction divisions seem not to have been observed in animals, but are known to occur spontaneously in plants, and have also been experimentally induced (cf. Battaglia ${ }^{5}$ ).

The micromeres and their descendants have very important functions. During the blastula stage this material has a high potency in restraining the tendencies towards extension of the animal differentiations and, when transplanted into isolated animal halves, in inducing vegetal differentiations ${ }^{\mathfrak{b}}$. Later, it produces skeletal substance. Possibly these functions depend upon the haploid state. An experimental analysis of these and related problems is in progress.

A detailed account of this work will appear in Experimental Cell Research.

Institute of Zoophysiology,

Per Eric Lindaht

University of Uppsala.

Dec. 9.

1 Zeuthen, E., Pubb. Staz. Napoli, 23, Supp., 47 (1951).

'Lindahl, P. E., Acta Zool., 17, 179, 258 (1936); 22, 101 (1941).

${ }^{3}$ Baltzer, F., Arch. Zellforsch., 2, 549 (1909).

"Darlington, C. D., "Recent Advances in Cytology" (Philadeiphia, 1937).

${ }^{6}$ Battaglia, E., Caryologia, 3, 79 (1950).

- Hörstadius, S., Pubb. Staz. Zool. Napoli, 14, 251 (1935).

\section{Reversal of Phototaxis in Prepupx of Hymenoptera (Tenthredinidæ) caused by Amyl Acetate Vapour emanating from Marking Paint}

IN autumn the grass-feeding larvæ of Tenthredopsis litterata Geoff. and T. nassata F. undergo an ecdysis prior to entering the soil at plant roots, where they remain as overwintering non-feeding prepupæ until pupation occurs in the following summer.

The newly formed prepupæ, although lethargic, exhibit positive phototaxis; but within a period of two or three days they become more active and photonegative. This negative phototaxis appears to direct them to the pupation site in soil, and at present there is no evidence that a gravity reaction is involved.

While investigating the details of the taxis mechanism, a cêllulose lacquer was used for occluding in part the vision of active photonegative prepupæ. For a period lasting from a fow minutes up to two hours, prepupæ so treated became strongly photopositive, but afterwards reverted once again to their pre-treatment photonegative condition. Further experiment showed that paint placed on other parts of the body produced the same effect, and that this reversal of reaction to light could also be caused by previous treatment for a short period with the vapour of amyl acetate, or handling by instruments contaminated by this vapour. Prepupæ so treated, after being photopositive for a while, returned to their original photonegative condition fairly abruptly and usually within a minute of such a reversal tendency being observed. Ethyl acetate, acetone and chloroform vapours did not alter the reactions of prepupæ to light.

The above observations were made in a dark room on prepupæ moving in a horizontal plane with respect to a diffuse lateral beam of light. The beam emanated from a 100-watt lamp bulb placed $45 \mathrm{~cm}$. from the experimental area and shone through an aperture $5 \mathrm{~cm} . \times 3 \mathrm{~cm}$. , across which was placed a glass vessel containing water. Further experiments were conducted to ensure that variation in light intensity, heat gradients, nature of substratum and previous exposure of prepupæ to light were not responsible for the observed reversal of behaviour.

Since amyl acetate is a constituent of paints which may be used in various experiments involving insect behaviour, it is felt that these observations might be of particular interest to workers in such fields.

University College

\section{F. L. WATERhouse}

(University of St. Andrews), Dunde日.

Dec. 24 .

\section{Manganese Requirements of Tomato Plants at Different Phases of Growth}

DURING investigations on the iron and manganese requirements of plants ${ }^{1}$, it was decided to determine whether tomato plants required a continuous supply of manganese throughout their growth or whether the element was more essential at one phase than at another. Investigations on similar lines have been reported by Gericke ${ }^{2}$ for wheat and by Brenchley ${ }^{3}$ for barley. These workers, however, were concerned with the major nutrient elements.

The method used was the water culture technique ${ }^{2}$ and the general plan of the experiment is shown in Table 1 .

\begin{tabular}{|c|c|c|c|c|}
\hline $\begin{array}{l}\text { Treatment } \\
\text { designation }\end{array}$ & $\begin{array}{l}\text { Period I } \\
1 \text { st } \\
2 \text { weeks }\end{array}$ & $\begin{array}{l}\text { Period II } \\
\text { 2nd } \\
2 \text { weeks }\end{array}$ & $\begin{array}{c}\text { Period III } \\
\text { 3rd } \\
2 \text { weeks }\end{array}$ & $\begin{array}{l}\text { Period IV } \\
4 \text { th } \\
2 \text { weeks }\end{array}$ \\
\hline $\begin{array}{l}A \\
B \\
C \\
D\end{array}$ & $\begin{array}{l}+M n \\
+M n \\
+M n \\
+M n\end{array}$ & $\begin{array}{l}-M n \\
+M n \\
+M n \\
+M n\end{array}$ & $\begin{array}{l}-M n \\
-M n \\
+M n \\
+M n\end{array}$ & $\begin{array}{l}-\mathrm{Mn} \\
=\mathrm{Mn} \\
\overline{-M n} \\
+\mathrm{Mn}\end{array}$ \\
\hline $\begin{array}{l}E \\
F \\
G \\
H\end{array}$ & $\begin{array}{l}-M n \\
=M n \\
=M n \\
=M n\end{array}$ & $\begin{array}{l}+M n \\
=M n \\
=M n \\
-M n\end{array}$ & $\begin{array}{l}+M n \\
+M n \\
+M n \\
-M n\end{array}$ & $\begin{array}{l}+M n \\
+M n \\
+M n \\
-M n\end{array}$ \\
\hline
\end{tabular}

Manganese as manganese chloride and iron as ferric citrate were supplied at concentrations of 0.5 p.p.m. manganese and 1.0 p.p.m. iron in the culture solution. After a two-week germination period in the absence of iron and manganese, the seedlings were transferred to the various treatments (four replicates of each). The culture solution was changed weekly. 